\title{
SOCIAL HOUSING IN SLOVAKIA. THE TASK AND JUSTNESS OF THE NON-PROFIT HOUSING ORGANIZATIONS ESTABLISHMENT IN SLOVAKIA
}

\author{
L'ubomíra ČERVEŇOVÁ \\ Department of Economics and Building Industry Management, Slovak University of Technology, \\ Radlinského 11, 81368 Bratislava, Slovakia \\ E-mail: cervenova@svf.stuba.sk
}

Received 11 October 2004; accepted 23 March 2005

\begin{abstract}
The paper deals with the situation in the housing sector in Slovakia since 1990. It presents changes in the structure of the tenure, the growth of the owner-occupied housing and decline of rental housing stock. It describes activities, policy and goals of public rental housing sector. It is concerned on a $\square$ justness of a non-profit housing organization establishment in this country. This institution would represent a $\square$ new approach in the re-development of rental housing in Slovakia. It describes the first experiences from the establishment of the non-profit housing organization and shows the possible risks, that could endanger the function of this institution.
\end{abstract}

KEYWORDS: Housing stock; Rental housing; Non-profit housing organization; Risks

\section{INTRODUCTION}

The Slovak housing policy has been influenced by changes of the political system in the nineties of the 20th century. The arrangement of objectives of the housing policy has affected a further development of housing sectors and a structure of a housing stock. The privatization of state rental flats by tenants and a reduction of the new rental houses construction has caused the increase of the owner-occupied housing sector at the expense of rental housing. The state has shifted a responsibility for a repair and an upkeep by privatization on the new owners. At the first it was believed, that every individual should take care of his/her housing needs without governmental aid, but soon it became clear that this has been practically infeasible. It was necessary to develop a housing policy including a new sustainable housing finance system that would enable to fund an affordable housing schemes for all layers of population [9]. The attenuation of the development of a rental housing sector has evoked some limitations on a housing market. It is useful to ensure a certain number of rental flats in the country because of the labour mobility.

A private rental housing sector has started to develop in Slovakia. It offers rental for a market prices and is often provided on the black market.

A public rental housing sector has been managed by municipalities, but regarding lack of finances, the development of this sector is slow and a demand for this type of housing has been not satisfied. Living in municipal flats is restricted and is offered just to those persons concerned, who are able to fulfil certain criteria (monthly income of household is maximum three and a half fold of living wages and a period of use is maximum three years).

A purchase or a construction of real estate is determined mostly by finances of persons concerned, that depend on a volume of their incomes and savings. Concerning a decline of a living standard it would be useful to develop 
a rental housing sector. At present it represents cca. $8 \%$ of the whole housing stock in Slovakia. A share of rental housing sector of the whole housing sector is considerably higher in various countries of the Western Europe [10].

\section{THE STRUCTURE OF THE HOUSING STOCK IN SLOVAKIA}

The state housing policy in the nineties of the 20th century was characterized by its tendency of a privatization of a rental housing stock by tenants. The state has shifted a responsibility for a housing stock (upkeep and repair) by this approach on new owners - inhabitants. This change has carried plenty of assets - new owners have been motivated in maintenance of their dwellings and common indoor spaces. It has supported a flexibility and a realization of their intentions and ideas. But due to a fact, that in the mentioned period a new construction of rental flats was very low, an affordability of rental dwellings has become restricted.

A period from 1991 - 2001 is typical for its strong change in a tenure of a housing stock. Comparing figures elaborated by the Statistical Office of Slovak republic in the years 1991 and 2001 flows, that in the mentioned period a share of rental flats in Slovakia has declined on $8,1 \%$ from the whole housing stock in this country. A detailed information is shown in Table 1, Figure 1 and Figure 2 enclosed below.

Table 1. Tenure in Slovakia

\begin{tabular}{llll}
\hline Type of dwelling & Specific & Year & Year \\
& number & 1991 & 2001 \\
\hline Dwellings in owner-occupied family houses & $\%$ & 50,2 & 47,1 \\
Owner-occupied dwellings in multi-family houses & $\%$ & 5,2 & 26,7 \\
Other dwellings free of charged & $\%$ & 0,2 & 1,0 \\
Rental dwellings & $\%$ & 21,2 & 8,1 \\
Co-operative departments & $\%$ & 22,1 & 14,9 \\
Caretaker, service dwellings & $\%$ & 0,8 & 0,5 \\
Other and undetected dwellings & $\%$ & 0,3 & 1,7 \\
\hline Sum & $\%$ & 100,0 & 100,0 \\
\hline
\end{tabular}

Source: Statistical Office of Slovakia, 2001

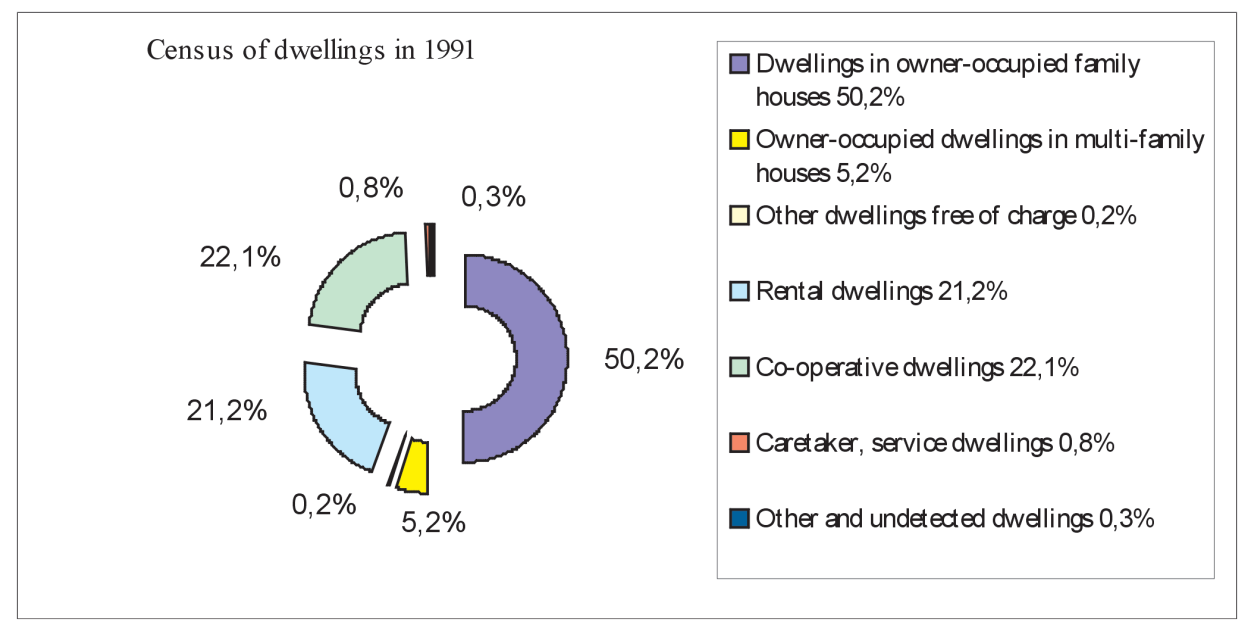

Figure 1. Census of dwellings in 1991, Source: Statistical office of Slovakia, 2001 


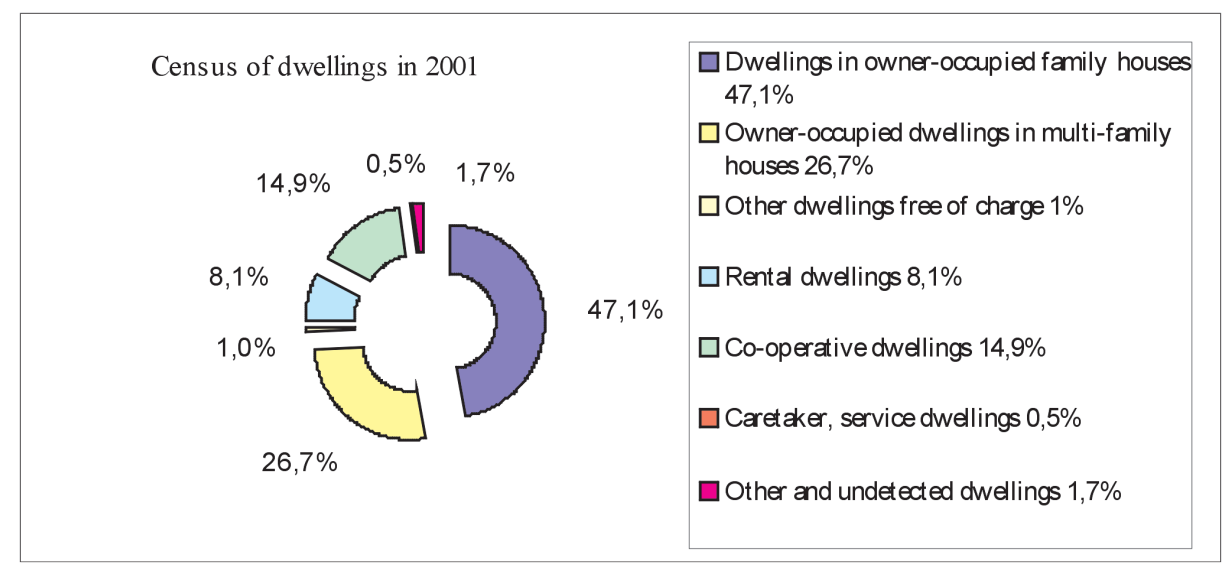

Figure 2. Census of dwellings in 2001, Source: Statistical office of Slovakia, 2001

The increase of owner-occupied housing sector at the expense of rental housing has restricted the affordability of housing. The development of rental housing would besides a possibility of ensuring dwelling through mortgage credits and construction savings help those, who need to solve their housing problem, but do not have a cash to take some credits. Affordable housing can be thought of as physically adequate housing that is made available to those who without some special inter- vention by government or special arrangement by the providers of housing, could not afford the rent or mortgage payments for such housing [6]. Municipalities try to solve this situation through a construction of rental flats that include to public rental housing sector. Its realization is subsidized by the Ministry of Construction and Regional Development of Slovak Republic (MCRD SR).

A detailed review about a tenure structure of housing stock is noted in the Table 2 below.

Table 2. The Tenure Structure and the Legal Titles of the Use of Permanently Occupied Dwellings in Slovakia (5/ 2001)

\begin{tabular}{|c|c|c|c|c|c|c|c|}
\hline \multirow{2}{*}{$\begin{array}{l}\text { Legal title of the use } \\
\text { of the dwelling }\end{array}$} & \multicolumn{7}{|c|}{ Owner of the house with the dwelling (housing unit) } \\
\hline & $\begin{array}{l}\text { Natural } \\
\text { person }\end{array}$ & State & Municipality & $\begin{array}{l}\text { Housing } \\
\text { cooperative }\end{array}$ & $\begin{array}{l}\text { Mixed } \\
\text { ownership }\end{array}$ & $\begin{array}{l}\text { Other and } \\
\text { unknown } \\
\text { type of the } \\
\text { ownership }\end{array}$ & $\begin{array}{l}\text { Total } \\
\text { number } \\
\text { of } \\
\text { dwellings }\end{array}$ \\
\hline Total & 916,610 & 20,847 & 39,676 & 194,723 & 410,528 & 83,152 & $1,665,536$ \\
\hline $\begin{array}{l}\text { Dwellings in owner- } \\
\text { occupied family houses }\end{array}$ & 774,175 & 75 & 79 & 33 & 3,285 & 6,083 & 783,73 \\
\hline $\begin{array}{l}\text { Owner-occupied dwellings } \\
\text { in multi-family houses }\end{array}$ & 108,485 & 2,369 & 4,019 & 33,18 & 260,093 & 37,201 & 445,347 \\
\hline $\begin{array}{l}\text { Other dwellings free of } \\
\text { charge }\end{array}$ & 13,076 & 0 & 0 & 0 & 1,457 & 1,217 & 15,75 \\
\hline Rental dwellings & 13,105 & 12,777 & 32,953 & 8,151 & 44,045 & 24,194 & 135,225 \\
\hline Co-operative dwellings & 5 & 0 & 8 & 150,829 & 91,272 & 6,417 & 248,531 \\
\hline Caretaker, service dwellings & 217 & 3,732 & 551 & 116 & 741 & 3,021 & 8,378 \\
\hline $\begin{array}{l}\text { Other and undetected } \\
\text { dwellings }\end{array}$ & 7,547 & 1,894 & 2,066 & 2,414 & 9,635 & 5,019 & 28,575 \\
\hline
\end{tabular}

Source: K. Ivanička, Update of Slovak Housing Sector Profile, Slovak University of Technology, Bratislava, 2004, p. 13. 
A proper definition of a term social housing is missing in the present state housing policy. An accurate characteristics of this type of housing and a key group of tenants fails. It is important to make this term clear and to realise that social housing is a suitable type of housing for those, whose incomes are lower, but they are able to take care of themselves, to pay a rent and other fees in time. It is incorrect to define social housing as a housing for asocial groups of inhabitants. According to Best [1], social housing is a term used throughout the member countries of the European Union to refer not just to public housing but to other accomodation subsudized by public sources. In the United Kingdom, social housing can embrace public housing often called (council housing) and also the homes of housing associations. Public housing was not initially designed to house the poorest of the poor [5].

\section{PUBLIC RENTAL HOUSING SECTOR}

On the basis of the Law of the Parliament of Slovak Republic No. 518/ 1990 Coll. on the transition of the foundation function from national committies toward municipalities, central bodies of Civil Service and local Civil Service bodies, the Housing Boards were shifted in the year 1990 in the sphere of action of municipalities. By setting the Law of the Parliament of Slovak Republic No. 138/ 1991 Coll. on the municipal property were flats and nonhousing spaces, that were previosly in the sphere of action of Housing Boards put in the ownership of municipalities according to a regional principle. This change has shifted a responsibility for ensuring of a housing to municipalities.

Well-functioning housing sector should ensure a provision of adequate and affordable housing for all inhabitants [18]. At present, a development of public rental flats is restricted and is in regard to a demand insufficient. The municipal housing development is focused on a construction of social flats, that can be rented just for three years to a tenant. This period of a usage of a flat is too short. Those flats are set for households with a maximum income of three and a half fold of living wages. It results from Table 2, that municipal rental flats represent just $1,98 \%$ from the whole housing stock. This figure is in respect to an existing demand for the mentioned type of housing low. Non-profit housing association should be a new solution of housing problems of municipalities.

\section{MISSION OF THE NON-PROFIT HOUSING ASSOCIATION IN SLOVAKIA}

Non-profit housing associations will represent new attitude of ensuring of affordable housing in Slovakia. Their mission as a public useful institution will be a development of housing for a key group of tenants, i. e. middle and low income groups of inhabitants. The mentioned institutions will represent social developers. These entrepreneurs understand by the term social housing in the first place social offer, not a business. A viability of this organization is set by its profit activities (a construction of detached houses, multi-family houses for a purpose of sale, leasing of luxurious flats) and thereafter by a profit re-investment from these activities into social housing development.

These organizations are typical for the Netherlands, where they have more than 100 years history. In about 1850, the first building societies were established. Those societies were set up by the prosperous bourgeoisie to build dwellings for their employees for a satisfactory return, with a social goal linked to recognized self-interest. A boom of social housing development has arrived after the second world war, when a necessity for a new housing construction has arisen due to a war damages. Nowadays, the Dutch housing associations are independant, private organizations, but with a public responsibility. They are not subsidised from the state anymore [13]. Regarding the legal status of housing associations, many of them have recently been converted into foundations and thereby achieved greater manage- 
rial independence. At the same time housing associations face greater financial risk and increased uncertainity [3].

A process of an establishment of non-profit housing association in Slovakia is in its preparatory phase. The initiative has been stimulated by the Matra grant of the Netherland's Kingdom. The aim of the grant is a support of those states, that are typical for their changes in a society - a transformation of a socialist adjustment into plural democracy. A programme has two levels: civil and national. The main idea is to support a development of a civil society, that is opened toward inhabitants. This programme is oriented on an improvement of function conditions of public institutions, their administration, social policy and ensuring of a transparency. Within this programme a co-operation of the Dutch specialists in the sphere of housing - representatives of housing associations and consultant agency (Vestia, PRC Bouwcentrum) and financial institutions (DIGH - Dutch International Guarantees for Housing) with representatives of our state institutions and municipal bodies. A goal of this co-operation is to modify a legal and financial framework needful for the establishment of non-profit housing associations.

Nowadays, affordable housing is developed by municipalities in Slovakia, that represents public rental housing sector. These co-operators tried to find and address a municipality, that is interested in a pilot project of establishment and function of non-profit housing association. The objective of the mentioned project is to examine legal and financial environment, that would affect the activities of nonprofit housing associations and to regulate them to support their activities.

Many Slovak municipalities were invited to several workshops focused on a publicity of a non-profit housing sector in the Netherlands and possibilities of its development in Slovakia. Their main objective has been stimulation of municipalities in the sphere of an establishment of non-profit housing organizations. A serious interest for a foundation of such an organiza- tion has been showed from the municipality of the city of Martin from the great number of municipalities.

\section{THE ESTABLISHMENT OF NON- PROFIT HOUSING ASSOCIATION IN THE CITY OF MARTIN}

The city of Martin is interested in the establishment of the non-profit housing association. The pilot project of the non-profit housing association can start after a decision about the housing stock, that will be shifted into the asset of this new organization. On the present, the municipal housing fond is managed by a managing company Martico, ltd. This firm is responsible for 26 municipal rental houses, that differ from each other in an age, maintenance, locality, they are situated in and tenants. Most of these houses are in a very bad technical status, because of problematic tenants - bad payers.

A non-profit housing organization should be viable therefore all possible risks should be adjusted. It is important to define a housing stock, that should be an asset of a new housing association. The aim is to choose maintened houses with tenants, that pay their rent in time. Four rental houses accomplish this criterium. If incorrect houses were chosen, there would be a risk of problematic tenants and would lose finances. The other possibility is to evacuate bad payers according a legal formula, demolish a destroyed housing stock and construct new houses. For easier realization of this idea it would be better, if a non-profit association owned lands under those houses.

The next criteria is a securing of a good position of rental flats in the market. Those flats should be competitive with a standard floor space. Public and assisted housing rules that have locked families into substandard housing have impeded their ability to move to self-sufficiency. Affordable housing serves as a starting point for families working toward stability and self-sufficiency by emphasizing work, education and stability [2]. There are several 
programes, e. g. the Family Self-Sufficiency program designed to coordinate the use of public housing and public and private resources to enable eligible families to achieve economic independence [7].

The non-profit housing organization should prevent creating social ghettos [8]. It is commonly recognized that the problems of severely distressed housing - often thought of as a matter of ill-conceived and deteriorating buildings - are also fully entwined with the socioeconomic problems of severely distressed public housing residents [15].

A level of a rent should be also considered properly according to an expected costs for maintenance and upkeep and other items. Knowledge of these costs will help to define a level of a rent properly, to have enough finance for a maintenance and to create a fund for a repair and an upkeep. It should be specified whether a rent will be collected for a one month in advance. A level of a rent could depend on a fact, that some loans are taken. An inherent tension exists between making a property affordable to lower-income residents and making it economically viable [14].

The next criteria is a selection of tenants. It would be useful to create a procedure of their selection, define conditions of a selection.

Key clients of a non-profit association will be sectionalized in these groups:

a) Young families;

b) Clients with lower incomes;

c) Clients with moderate income;

d) Clients who have come to a region because of a work.

\section{SWOT ANALYSIS OF THE ESTABLISHMENT OF A NON-PROFIT HOUSING ASSOCIATION IN THE CITY OF MARTIN}

It is convenient to know positives and negatives of a project before a realization of a mentioned intention (an establishment of a nonprofit housing association) to know merits and risks. SWOT analysis is usually made for such a purpose. It shows strong and weak sides of a project, defines opportunities and tensions, that could influence its viability.

SWOT analysis of a non-profit housing association establishment in the city of Martin:

\section{STRENGTHS:}

$\checkmark$ Securing of rental housing in the city,

$\checkmark$ Maintenance and upkeep of the housing stock,

$\checkmark$ Maintenance of an environment,

$\checkmark$ Support of a mobility of inhabitants,

$\checkmark$ Social aspect.

WEAKNESSES:

$\checkmark$ Financial limitations in the beginning of its activity,

$\checkmark$ Legal and financial framework.

\section{OPPORTUNITIES:}

$\checkmark$ Development of housing in the city of Martin,

$\checkmark$ Development of a car industry in the city of Žilina (close to Martin) and necessity of securing of housing for employees,

$\checkmark$ International know- how in the sphere of housing development.

\section{THREATS:}

$\checkmark$ Badly compiled business plan,

$\checkmark$ Badly chosen a key group of tenants => problems with their behaving and payments of rent in time,

$\checkmark$ High operation costs.

The SWOT analysis shows, that the establishment of a non-profit housing organization would contribute to the development of a rental housing in the city. New housing units would be created and a mobility of inhabitants would be supported. The operation of this organization would be hard due to a lack of finances. Its interest should be put on a collection of finances, that would enable to construct new housing units to rent them to tenants and to 
collect rents. This phase would be facilitated by suitable legislative and financial conditions. A cooperation with foreign associations in the sphere of know-how would be contributing. A successful beginning of an organization could start after a correctly arranged business plan focused on a market research, risk assessment and a strategic management.

\section{BUSINESS PLAN OF THE NON- PROFIT HOUSING ORGANIZATION OF THE CITY OF MARTIN}

A non-profit housing association should create a business plan, that would be sustainable. A definition of a mission and aims should be a content of a strategy of this organization. An organizational structure should be designed. An analysis of participants, partners on local, national and international level should be elaborated. A market research should be done to find out a level of a demand for social flats and potencial extend of profit construction. A construction of social flats should react on a demand for that type of housing, so that they will not stay free. It is important to make a strategy, to assess risks, to do a programme of activities and an implementation of this programme, to assess a financial sustainability and to make decisions about financial planning. A non-profit housing association should plan and determine its investment costs, maintenance costs, material costs, organizational costs, insurance, taxes, bank fees and a reserve fund. Correctly arranged business plan is the first step to an establishment of a successful co-operation with business partners.

\section{THE RISKS CONNECTED WITH THE ESTABLISHMENT AND OPERATION OF THE NON- PROFIT HOUSING ORGANIZATION}

A non-profit housing organization, that is going to be founded in Slovakia should be viable. Therefore it is important to identify possible risks, that could influence its sustainability. The awareness of weaknesses of this organization, its threats in the preparatory phase of a project of a non-profit housing organization establishment gives ideas for their management and further successful activities. A viability of non-profit housing organizations could be endangered by following risks (see Figure 3).

\section{Risk No. 1: legislation}

The operation of non - profit organizations in Slovakia is defined by the Law of the Parliament of Slovak republic No. 213/ 1997 Coll. on the non-profit organizations rendering public services and its later decrees.

The existing law on the non-profit organization is valid for several types of the non-profit entities [19]. It would be more effective if a function of non-profit housing organizations was specified by a particular law on the function of the non-profit organizations only in the housing sector. The Ministry of Construction and Regional Development already undertook such
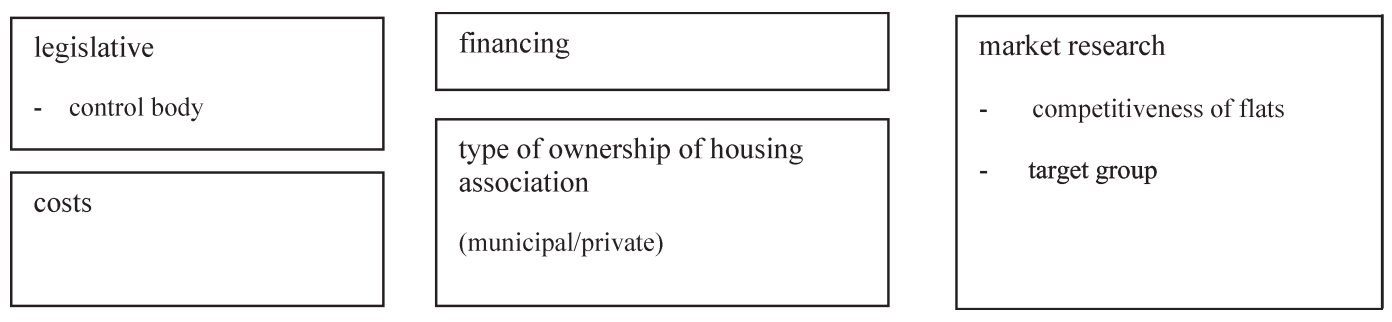

Figure 3. Risks connected with the establishment and operation of non-profit housing organization 
effort. Their iniciative has been rejected by the legislative experts, who argued that a mentioned change would interfere with the effort to create a transparent legislative system [10].

In practice it is not easy to create the nonprofit housing organization. The members of local parliament have to approve the establishment of the non-profit organization, but they often do not understand its benefits. The municipalities often want to exert a strong control on all operations related to the new social rental housing development. They have no experience in indirect control of non-profit housing organizations through a supervisory board. They are afraid of a financial tunnelling of the organization [10].

Nowadays, the Code on the non-profit law is being prepared. At present, it is in the phase of suggestion process of each department. It will present a core component of a new lefislation of a not for profit law. The Code on the nonprofit law should set up strong basis of function of not for profit sector. It should define rules of the activity of this sector. The aim of the mentioned code is to increase a transparency of nonprofit organization activities. A financial escapes could be a risk factor of housing associations with a low moral. The operation of non-profit housing organization should be monitored because of this reason by a control body.

Moreover the municipalities have also the right to create a contributory organizations that are tax-exempt and are subordinated to a municipality although they have their autonomy. The contributory organization is oriented on a new housing development, privatization, rent collection and housing management. The two latter activities are more often carried out by for-profit housing management limited corporations where a municipality is also a stockholder. The municipal contributory organization is often responsible for all the municipal real estate and infrastructure investments. Sometimes a concentration on the housing problems is weak. Moreover, the proceeds from rents and housing privatization may be used on the other purposes than for a housing [10].

\section{Risk No. 2: type of ownership of a non-} profit housing organization (municipal private)

There can be established two types of nonprofit housing organizations from the type of ownership point of view: municipal or private. It is expected, that a municipal non-profit housing organization will be established in Slovakia in a short period. This alternative is financially more convenient concerning a state's subvention, that can be given to an organization in case a municipal financial or other deposit is minimum $51 \%$ of a property of the organization according to a direction of the Ministry of Construction and Regional Development No. V$1 / 2004$. A risk of a municipal non-profit housing organization is a possible personal changes of employees of a municipal office because of a limited elections period. A municipal non-profit housing organization would be dependant on political preferences, people engaged in a local policy and their priorities in a sphere of social housing.

A private non-profit housing organization would be financially independent and self-contained from the attitudes of employees of local bodies. The association should accumulate enough finances needful for housing development. It would not be subsidized by state.

A fact, that private non-profit housing associations function more effectively than municipal has been approved by experiences from Great Britain, the Netherlands, Austria, etc. A private non-profit housing organization is due to its statute forced to be efficient, because this fact determines its further existence. Municipalities as a public legal bodies have to face problems, that are in a public economy marked as a "state defection“ or „public sector defection". This failure is connected with controversial political, economical and social objectives. It is caused by ineffective budgetary control and unflexible problems solving [16].

\section{Risk No. 3: financing}

It is important to ensure a certain amount of finances for a function of an organization. 
They can be collected from internal or external sources. Business partners should be specified for gaining external finances (i. e. financial institutions) [11].

A risk of scepticism of business partners towards a new ideas should be got under control before the establishment of not for profit housing association. A lot of energy should be spend on a publicity of a project, its substantiation and explanation. The objective of the mentioned activity is an ambition for persuading of business partners and making mutual co-operation.

In Great Britain, housing associations have been regarded as wholly private sector bodies since 1988. The basis for public funding of housing associations has remained the same: a capital grant toward the cost of development called the Housing Association Grant (HAG). Before 1988 , the grant would typically meet 75 to 100 percent of development costs, but the 1988 Housing Act required housing associations to raise a far greater proportion of their development costs through the private financial markets. The expenditure they incur in this way is not counted against public sector expenditure. However, the total amount of capital grants available (the Approved Development Programme, or $\mathrm{ADP}$ ) and the rate at which grants may be offered to associations are reviewed annually by the government. Because all local authority expenditure is subject to government control, the key advantage of housing associations is their ability to "gear" the ratio of public to private financing for new social housing [12].

\section{Risk No. 4: costs}

A critical contributing factor to the affordable housing problem is the high cost of producing new housing [4]. A municipal non-profit housing organization can demand for a state subsidy only in a case, that an average acquisition cost per $1 \mathrm{~m}^{2}$ of a floor space will not exceed 21, 430 SKK [17]. This financial restriction limits an optional sampling of construction materials. This fact tends to use those materials, that will not exceed a specified level of costs.

A possible risk of this selection can be in its orientation on prices of building materials more than on their quality. A low quality influences their operational life and increases costs for upkeep and repair. An increase of these costs could change a height of a rent and influence a popularity of this type of housing. It is important to choose building materials carefully because of this reason and to optimalize their selection in term of a price, but a quality, too.

\section{Risk No. 5: market research}

A market research helps in a correct heading of an investment process. Its initiation in a preparatory phase enables to know a market, its strenghts and weaknesses, a level of a competition, an offer of social housing and a demand for that type of housing. Finding out claims and needs of demand of people interested helps an intended project to be successful.

Those proposals, which enable an investment project to be competitive on a market, should be considered and processed in a project documentation. Projected houses should be of a suitable disposition with an average floor space. They should be attractive for people interested in term of their design and locality.

\section{CONCLUSIONS}

Non-profit housing organizations will represent a new attitude in an ensuring and development of rental housing in Slovakia. They will perform a social development corporation. They will react on a demand for social housing. More convenient conditions will be set up for potential tenants because of the increase of the offer of rental flats in the public rental housing sector. Possibility for gaining a rental flat and a period of its using will be arranged on the behoof of tenants. Strict criteria for a selection of tenants should be changed, i. e. an income of a household should not be higher than three and a half fold of a living wages (at 
the present a level of living wages in Slovakia is 4,580 SKK) and a period of its using maximum three years. A successful function of nonprofit housing organizations can be developed after defining possible risks, that could threaten their mission, aims and procedures. At the same time it is needful to find optimal solutions, submit proposals of arrangements, so that risks could be minimized.

\section{REFERENCES}

[1] R. Best, Successes, Failures and Prospects for Public Housing Policy in the United Kingdom, Housing Policy Debate, 7(3), 1996, p. 535-562.

[2] R. G. Bratt, Challanges Confronting Nonprofit Housing Organizations' Self-Sufficiency Programs, Housing Policy Debate, 9(4), 1998, p. 795-824.

[3] Ch. Donner, Housing Policies in the European Union, Edition 2000. 399 p.

[4] N. van Dyk, Financing Social Housing in Canada, Housing Policy Debate, 6(4), 1995, p. 815-848.

[5] G. Epp, Emerging Strategies for Revitalizing Public Housing Communities, Housing Policy Debate, 7(3), 1996, p. 563-588.

[6] Ch. G. Field, Building Consensus for Affordable Housing, Housing Policy Debate, 8(4), 1997, p. 801-832.

[7] L. Freeman, Interpreting the Dynamics of Public Housing: Cultural and Rational Choice Explanations, Housing Policy Debate, 9(2), 1998, p. 323-352.

[8] L. Freeman, Subsidized Housing and Neighborhood Ratial Transition: An Empirical In- vestigation, Housing Policy Debate, 11(1), 2000, p. 67-89.

[9] K. Ivanička, Contractual Savings for Housing in the Context of Slovak Housing Finance System, International Journal of Strategic Property Management, 7(2), 2003, p. 70-83.

[10] K. Ivanička, Update of Slovak Housing Sector Profile, STU Bratislava, 2004, p. 1-109.

[11] M. Lindfield, Housing Finance Guidelines, VNG uitgeverij, Den Haag, 2000, p. 22-26.

[12] G. Lomax, Financing Social Housing in the United Kingdom, Housing Policy Debate, 6(4), 1996, p. 849-865.

[13] A. Ouwehand, Dutch Housing Associations, OTB, Delft, 2002, p. 8-26.

[14] D. A. Smith, Market-to-Market: A Fundamental Shift in Affordable Housing Policy, Housing Policy Debate, 10(1), 1999, p. 143-182.

[15] L. J. Vale, Public Housing Redevelopment: Seven Kinds of Success, Housing Policy Debate, 7(3), 1996, p. 491-534.

[16] B. Valentová, Housing and housing policy in European Union, <http://www.mmr.cz> (In Czech), 23th March, 2004.

[17] The Direction of the Ministry of Construction and Regional Development No. V-1/2004 on rules for puting up subventions for rental housing development

[18] The World Bank, Housing Enabling Markets to Work, Vol. 1, No. 2, The World Bank, 1993, p. $1-114$.

[19] The Law of the Parliament of Slovak Republic No. 213/ 1997 Coll. on the non-profit organizations serving public services and its later decrees.

\section{SANTRAUKA}

SOCIALINIS BŪSTAS SLOVAKIJOJE. Ne pelno siekiančios būsto organizacijos įkūrimo Slovakijoje užduotis ir pagristumas

\section{Lubomíra ČERVEŇOVÁ}

Straipsnyje aptariama situacija būsto sektoriuje, kuri Slovakijoje susiklostė nuo 1990 metų. Jame apžvelgiami turto valdymo sistemos pasikeitimai, augantis gyvenamujų namų savininkų skaičius bei mažějantis nuomojamų būstų kiekis. Jame apžvelgiama valstybinio nuomojamo būsto sektoriaus veikla, politika ir tikslai. Pagrindinè dominanti tema yra ne pelno siekiančios būsto organizacijos įsteigimo pagrịstumas. Ši institucija atstovautų naujam požiūriui i nuomojamo būsto rinkos atkūrimą Slovakijoje. Straipsnyje apibūdinama pirmoji patirtis, igyta kuriant ne pelno siekiančią būsto organizaciją, ir nurodoma galima rizika, kuri gali kelti grèsmę šios institucijos funkcijoms. 